\title{
DAMPAK PENAMBANGAN BATUBARA TERHADAP KUALITAS AIR SUNGAI BATANG MANGGILANG DI JORONG SEBRANG PASAR KENAGARIAN MANGGILANG KABUPATEN 50 KOTA
}

\author{
Mulza Rois ${ }^{1}$, Andrizal ${ }^{2}$ \\ 1Sekolah Tinggi Keguruan dan Ilmu Pendidikan (STKIP) Muhammadiyah Muara Bungo \\ Jl. Rang Kayo Hitam, Cadika, Rimbo Tengah, Kabupaten Bungo, Jambi, 37211, Indonesia \\ 2Sekolah Tinggi Keguruan dan Ilmu Pendidikan (STKIP) Ahlussunnah Bukittinggi \\ Jl. Diponegoro No.8, Tarok Dipo Bukittinggi, Sumatera Barat 26117, Indonesia
}

Email: rois.mulza@gmail.com

\begin{abstract}
Abstrak
Penelitian ini bertujuan untuk mengetahui dampak penambangan batubara terhadap kualitas air Sungai Batang Manggilang di Jorong Sebrang Kenagarian Manggilang Kabupaten 50 Kota. Jenis penelitian ini merupakan penelitian eksperimen di lapangan yang dilanjutkan dengan analisis di laboratorium. Populasi dan sampel dalam penelitian ini adalah air Sungai Batang Manggilang yang diambil dengan cara sampling acak sederhana. Teknik pengambilan sampel adalah Sampel Komposit, Uji Coba Instrumen, Pengolahan Hasil Test. Hasil penelitian adalah (1) Kondisi Fisika (Warna, rasa, bau, kekeruhan, suhu) didaerah kenagarian manggilang yang berada dekat sungai batang manggilang sesuai dengan uji laboratorium bahwa air sungai ini tidak memenuhi syarat untuk dipergunakan oleh masyarakat yang berada di sekitar hulu sungai batang manggilang. Karena sudah tercemari oleh dengan keberadaan tambang batu bara. (2) Kondisi Kimia ( $\mathrm{pH}$, Zat tersuspensi, Besi ( $\mathrm{Fe}$ ) di daerah kenagarian manggilang sebrang pasar manggilang kabupaten 50 kota tidak memenuhi syarat sesuai yang ditetapkan mentri kesehatan no 492/PER/IV/tahun 2010. Sehingga hal ini sangat membahayakan bagi masyarakat yang menggunakan langsung air Sungai Batang Manggilang untuk keperluan sehari-hari.
\end{abstract}

Kata Kunci: Dampak, Pertambangan Batubara, Kualitas Air

\begin{abstract}
The research aims to determine the impact of coal mining on the water quality of Batang Manggilang River in Jorong Sebrang Kenagarian Manggilang Kabupaten 50 Kota. This type of research is an experimental research in the field followed by laboratory analysis. The population and sample used are simple random sampling. Sampling technique is Composite Samples, Test Instruments, Processing Test Results. The results of the research are (1) Physical Condition (Color, taste, odor, turbidity, temperature) in manggilang kenagarian area near manggilang rod river in accordance with laboratory test that the river water is not eligible for use by people around the river upstream manggilang. Because it is contaminated by the presence of coal mines. (2) Chemical condition $(\mathrm{pH}$, suspended substance, iron $(\mathrm{Fe})$ in kenagarian area manggilang sebrang manggilang market 50 municipal districts do not meet the requirements stipulated health minister no 492/ menkes / Physical Condition (Color, taste, odor, turbidity, temperature) in the kenagarian manggilang area near the river manggilang rod in accordance with laboratory tests that the river water is not eligible for use by people who are in the upper river rod manggilang.
\end{abstract}

Key word: Impacts, Coal Mining, Water Quality 


\section{PENDAHULUAN}

Indonesia dianugerahi sumber daya alam yang melimpah termasuk bahan galian tambang dan Indonesia memiliki ketergantungan tinggi terhadap pemanfaatan bahan galian tambang tersebut sebagai modal pembangunan. Dalam Undang-Undang 1945 pasal 33 ayat (3) dinyatakan "bahwa bumi dan air dan kekayaan alam yang terkandung di dalamnya dikuasai oleh negara dan digunakan sebesar-besarnya untuk kemakmuran rakyat". Air memiliki banyak fungsi, sebagai pelarut umum, air digunakan oleh organisme untuk reaksireaksi kimia dalam proses metabolisme serta menjadi media transportasi nutrisi dan hasil metabolisme (Wiryono, 2017). Adanya peningkatan jumlah penduduk menyebabkan semakin tingginya tingkat eksploitasi terhadap sumberdaya alam yang berupa air, tanah, udara maupun lahan (Astuti \& Berutu, 2012). Penurunan kualitas air tidak hanya diakibatkan oleh limbah industri, tetapi juga diakibatkan oleh limbahrumah tangga baik limbah cair maupun limbah padat (Lallanilla, 2016). Negara Kita sering kali dihadapkan pada kondisi dilematis antara pemanfaatan air secara optimal dengan kerugian lingkungan dan sosial, termasuk menyeimbangkan pertumbuhan dengan pemerataan (Marganingrum \& Noviardi, 2009). Secara umum industri pertambangan memberikan kontribusi signifikan dalam ekonomi nasional (3\% PDB 2006) (Sulaksono, 2015). Keuntungan ekonomis bagi Indonesia lebih berarti dibandingkan dengan jumlah kontribusi dalam PDB, kerena multiplier effect yang dihasilkan meskipun sifatnya intangible. Menurut Sutedi (2016) pertambangan adalah serangkaian kegiatan dalam rangka upaya pencarian, penambangan (penggalian), pengolahan, pemanfaatan dan penjualan bahan galian (mineral, batubara, panas bumi, migas).

Salah satu pertambangan yang menghasilkan bagi investor Indonesia adalah pertambangan batubara. Bahan galian batubara adalah bahan galian yang terbentuk dari sisa tumbuhan yang terperangkap dalam sedimen dan dapa dipergunakan sebagai bahan bakar, jenis sedimen ini terperangkap dan mengalami perubahan material organik akibat timbunan (Burial) dan diagenesa (Manik, 2013). Batu bara awalnya merupakan bahan organik yang terakumulasi dalam rawa-rawa yang dinamakan peat (Widyati, 2009). Batu bara juga batuan organik yang memiliki sifatsifat fisika dan kimia yang kompleks yang dapat ditemui dalam berbagai bentuk. Pembentukan batu bara memerlukan kondisi-kondisi tertentu dan hanya terjadi pada era-era tertentu sepanjang sejarah geologi. Zaman karbon kira-kira 340 juta tahun yang lalu adalah masa pembentukan batu bara yang paling produktif (Jamilatun, 2008).

Sumatera Barat merupakan salah pusat industri pertambangan dengan segala potensi yang dimiliki, salah satunya adalah pertambangan batubara dengan nama PT.MBM merupakan cabang dari Kalimantan. Dalam pengamatan sementara permasalahan yang terdapat di lokasi penelitian adalah Pertambangan Batubara ini berdampak terhadap lingkungan serta banyak terdapat keluhankeluhan dari masyarakat yang berada di sekitar kawasan ini. Dahulunya Sungai Batang Manggilang ini dimanfaatkan masyarakat sebagai kegiatan sehari-hari, seperti mandi, nyuci, serta menangkap ikan. Dikarenakan sungai ini memiliki kualitas air yang cukup bersih dan jernih, tidak tercemar oleh bahan kimia. Setelah dibangun pertambangan batu bara di hulu Sungai Batang Manggilang menyebabkan air Sungai ini mengalami penurunan kualitas air. Berdasarkan beberapa fenomena tersebut maka perlu dilakukan penelitian mengenai dampak pertambangan batubara terhadap kualitas air sungai batang manggilang.

\section{METODE PENELITIAN}

Metode penelitian yang digunakan adalah metode eksperimen laboratorium. Arikunto (2009) menyatakan penelitian 
eksperimen merupakan penelitian yang dimaksudkan untuk mengetahui ada tidaknya akibat dari sesuatu yang dikenakan pada subjek selidik. Dengan kata lain penelitian eksperimen mencoba meneliti ada tidaknya hubungan sebab akibat. Populasi adalah keseluruhan dari objek penelitian yang dapat berupa manusia, hewan, tumbuh-tumbuhan, udara, gejala, nilai, peristiwa, sikap hidup dan sebagainya. Sehingga objek-objek ini dapat menjadi sumber data penelitian.

Populasi penelitian ini adalah air sungai batang manggilang di daerah manggilang, Kecamatan Pangkalan Kabupaten 50 Kota. Teknik pengambilan sampel yang digunakan adalah sampel komposit (Composite Sample), yaitu sampel campuran dari beberapa waktu pengamatan. Pengambilan sampel komposit dapat dilakukan secara manual ataupun secara otomatis dengan menggunakan peralatan yang dapat mengambil air pada waktu-waktu tertentu. Instrument penelitian adalah Botol Plastik,Alat Tulis, Kalkulator serta Komputer. Uji Coba Instrumen dalam suatu penelitian hasilnya dapat di percaya atau valid apabila data yang digunakan benar-benar akurat dan kualitas yang mana terlebih dahulu dilakukan uji coba instrument. Uji coba instrument ini menggunakan uji laboratorium.

Pengolahan hasil tes dengan cara tabulasi. Tabulasi yaitu dengan melakukan pembagian data yang telah diperoleh kedalam bentuk-bentuk tabel-tabel tertentu, guna mempermudah analisis data selanjutnya. Secara operasional, dalam penelitian kuantitatif terdapat beberapa tahapan dan langkah-langkah (Maleong, 2007).

1. Tahap pra lapangan yaitu :

a) Peneliti menyusun rencana dan rancangan penenlitian.

b) Menentukan titik lokasi sampling.

c) Peneliti mempersiapkan segala keperluan administratif penelitian, khususnya untuk persetujuan rencana dan lokasi penelitian.

d) Menyiapkan perlengkapan penelitian.

2. Tahap pekerjaan lapangan

a) Memasuki daerah penelitian.

b) Mempersiapkan alat dan bahan yang akan diperlukan.

c) Membawa sampel ke laboratorium.

d) Mengumpulkan data.

Teknik analisa data pada penelitian ini adalah analisis laboratorium kemudian data uji laboratorium dicocokkan dengan kategori baku mutu Keputusan Tentang Standar Kualitas Air Peraturan Mentri Kesehatan No. 492/Menkes/ per / IV / 2010 Tanggal 19 April 2010 dengan kualitas air sungai. Dapat dilihat pada Tabel 1 berikut ini.

Tabel 1. Keputusan Tentang Standar Kualitas Air Peraturan Mentri Kesehatan No. 492/Menkes/per / IV/2010 Tanggal 19 April 2010

\begin{tabular}{|c|c|c|c|}
\hline $\begin{array}{l}\mathbf{N} \\
\mathbf{o}\end{array}$ & Jenis Parameter & Satuan & $\begin{array}{c}\text { Kadar Maksimum Yang } \\
\text { Diperbolehkan }\end{array}$ \\
\hline \multirow[t]{13}{*}{1} & \multicolumn{3}{|c|}{ Parameter yang berhubungan langsung dengan kesehatan } \\
\hline & Parameter mikrobiologi & & \\
\hline & 1) e.coli & $100 \mathrm{ml} / \mathrm{sampel}$ & 0 \\
\hline & 2) Total Bakteri Koliform & $100 \mathrm{ml} / \mathrm{sampel}$ & 0 \\
\hline & b. Kimi anorganik & $\mathrm{ml} / \mathrm{l}$ & \\
\hline & 1) arsen & $\mathrm{ml} / \mathrm{l}$ & 0,01 \\
\hline & 2) flourida & $\mathrm{ml} / \mathrm{l}$ & 1,5 \\
\hline & 3) total kromium & $\mathrm{ml} / \mathrm{l}$ & 0,05 \\
\hline & 4) kadmium & $\mathrm{ml} / \mathrm{l}$ & 0,003 \\
\hline & 5) nitrit & $\mathrm{ml} / \mathrm{l}$ & 3 \\
\hline & 6) nitrat & $\mathrm{ml} / \mathrm{l}$ & 50 \\
\hline & 7) sianida & $\mathrm{ml} / 1$ & 0,07 \\
\hline & 8) selenium & $\mathrm{ml} / \mathrm{l}$ & 0,01 \\
\hline \multirow[t]{3}{*}{2} & \multicolumn{3}{|c|}{ Parameter yang tidak langsung berhubungan dengan kesehatan } \\
\hline & a. paramter fisik & & \\
\hline & 1) bau & & Tidak berbau \\
\hline
\end{tabular}




\begin{tabular}{|c|c|c|c|c|}
\hline $\begin{array}{l}\mathbf{N} \\
\mathbf{o}\end{array}$ & \multicolumn{2}{|r|}{ Jenis Parameter } & Satuan & $\begin{array}{c}\text { Kadar Maksimum Yang } \\
\text { Diperbolehkan }\end{array}$ \\
\hline & 2) & warna & TCU & 15 \\
\hline & 3) & total zat padat terlarut (TDS) & $\mathrm{mg} / \mathrm{l}$ & 500 \\
\hline & 4) & kekeruhan & NTU & 5 \\
\hline & 5) & rasa & & Tidak berasa \\
\hline & 6) & suhu & C & Suhu udara +-3 \\
\hline & $\mathrm{b}$. & parameter kimiawi & & \\
\hline & 1) & aluminium & $\mathrm{ml} / \mathrm{l}$ & 0,2 \\
\hline & 2) & besi & $\mathrm{ml} / \mathrm{l}$ & 0,3 \\
\hline & 3) & kesadahan & $\mathrm{ml} / \mathrm{l}$ & 500 \\
\hline & 4) & kholorida & $\mathrm{ml} / \mathrm{l}$ & 250 \\
\hline & 5) & mangan & $\mathrm{ml} / \mathrm{l}$ & 0,4 \\
\hline & $6)$ & $\mathrm{pH}$ & $\mathrm{ml} / 1$ & $6,5-8,5$ \\
\hline
\end{tabular}

Sumber: Depkes RI, 2010

\section{HASIL DAN PEMBAHASAN}

Air sungai di daerah ini memiliki 8 kerateristik Parameter air yang diambil berdasarkan aliran sungai. Sampel air sungai ini dianalisis di UPTD Balai
Laboratorium Kesehatan Propinsi Sumatera Barat. Lokasi penelitian dapat dilihat pada Gambar 1 berikut.

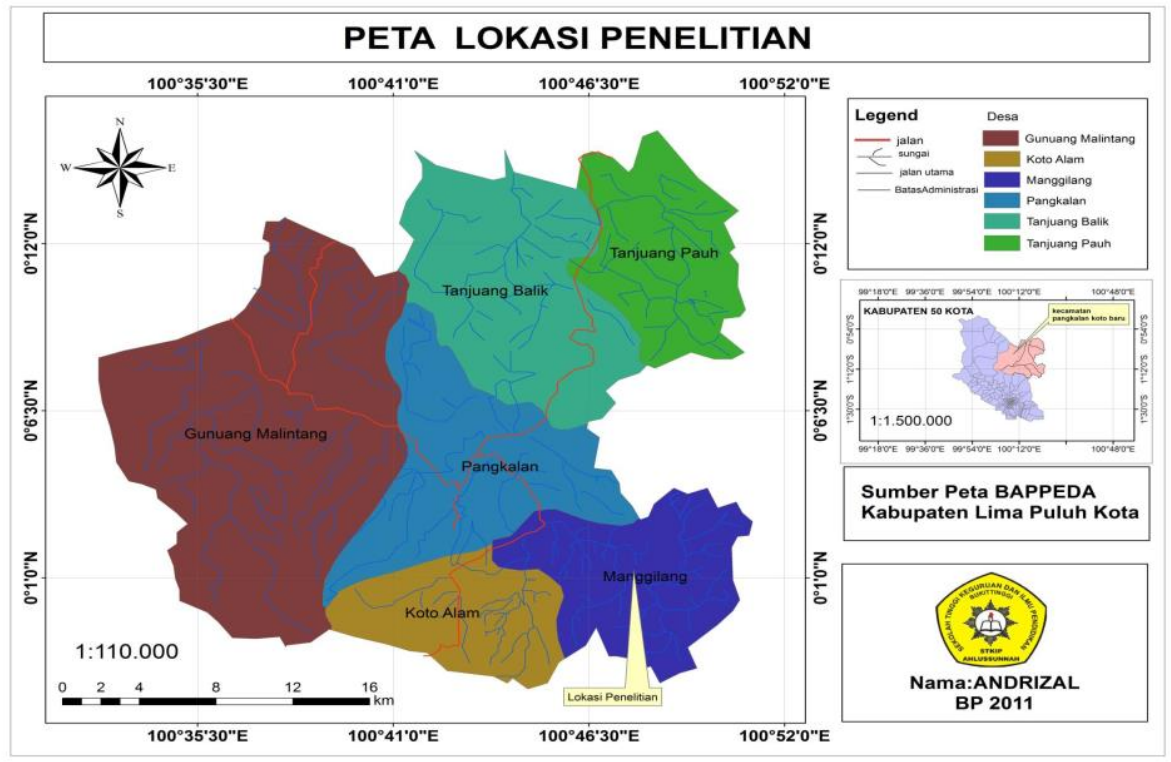

Gambar 1. Peta Lokasi Penelitian

Untuk mengetahui kualitas air sungai secara Fisika dan kimia. Pada aliran sungai yang ada di daerah kenagarian Manggilang sebagai berikut:

a. Sifat Fisika Air Sungai

1) Warna

Warna perairan biasanya dikelompokkan menjadi dua yaitu: warna sesungguhnya dan warna tampak. Warna sesungguhnya adalah warna yang disebabkan oleh bahan-bahan kimia terlarut. Warna tampak adalah warna yang tidak hanya disebabkan oleh bahan terlarut tetapi juga oleh bahan tersuspensi. Dari hasil penelitian dilaboratorium warna 0,5 TCU. Berdasarkan keputusan Mentri Kesehatan No 492/Menkes/per/IV/tahun 2010. Warna pada air maksimal 15 NTU jadi dari hasil penelitian yang didapat dari laboratorium tidak memenuhi syarat yang ditetapkan Mentri Kesehatan No 492/Menkes/per/IV/tahun 2010. Untuk lebih jelasnya dapat dilihat pada Tabel 2 . 
Tabel 2. Hasil Penelitian Warna Air Sungai Batang Manggilang

\begin{tabular}{|c|c|c|c|c|c|}
\hline \multirow{2}{*}{ No } & \multirow{2}{*}{ Parameter } & Satuan & \multirow{2}{*}{ MDL } & Sampel & \multirow{2}{*}{ Rekomendasi } \\
& & & & L. 3884 & \\
\hline 1 & Warna & TCU & 0,5 & 4 & Tidak Memenuhi Syarat \\
\hline
\end{tabular}

Sumber: Hasil Penelitian, 2014

2) Rasa

Dari hasil penelitian dilaboratoriun, rasa tidak berasa berdasarkan keputusan menteri kesehatan No 492 /Menkes/per/IV/tahun 2010. Jadi dari hasil penelitian yang didapat dari laboratorium memenuhi syarat yang ditetapkan Mentri Kesehatan no 492/Menkes/per/IV/tahun 2010. Untuk lebih jelasnya dapat dilihat pada Tabel 3 berikut ini.

Tabel 3. Hasil Penelitian Rasa Air Sungai Batang Manggilang

\begin{tabular}{|c|r|l|l|l|l|}
\hline No & Parameter & Satuan & MDL & Sampel & \multirow{2}{*}{ Rekomendasi } \\
\cline { 5 - 5 } & Rasa & - & - & $\begin{array}{l}\text { Lidak } \\
\text { Berasa }\end{array}$ & Memenuhi Syarat \\
\hline
\end{tabular}

Sumber: Hasil Penelitian, 2014

3) Bau

Dari hasil penelitian dilaboratoriun bau, berbau lumpur berdasarkan keputusan Mentri Kesehatan no /Menkes/per/IV/tahun 2010. Jadi dari hasil penelitian yang didapat dari laboratorium tidak memenuhi syarat yang ditetapkan Mentri Kesehatan No 492/Menkes/per/IV/tahun 2010. Untuk lebih jelasnya dapat dilihat pada Tabel 4 .

Tabel 4. Hasil Penelitian Bau Air Sungai Batang Manggilang

\begin{tabular}{|c|c|c|c|c|c|}
\hline No & parameter & Satuan & \multirow{2}{*}{ MDL } & sampel & Rekomendasi \\
\cline { 5 - 5 } 1 & bau & - & - & $\begin{array}{c}\text { L.3884 } \\
\text { lumpur }\end{array}$ & Tidak memenuhi syarat \\
\hline
\end{tabular}

Sumber: Hasil Penelitian, 2014

4) Kekeruhan

Kekeruhan air tergantung pada warna. Kekeruhan merupakan ukuran transparansi perairan yang ditentukan secara visual. Dari hasil penelitian laboratorium kekeruhan 0.02 NTU.
Berdasarkan keputusan Menteri Kesehatan No. 429/ Menkes/ PER/ IV/ Tahun 2010. Kekeruhan maksimal 5 jadi dari hasil penelitian yang didapat dari laboratorim tidak memenuhi syarat seperti yang tertera di Tabel 5 berikut ini.

Tabel 5. Hasil Penelitian Kekeruhan Air Sungai Batang Manggilang

\begin{tabular}{|c|l|c|c|c|c|}
\hline \multirow{2}{*}{ No } & \multirow{2}{*}{ Parameter } & \multirow{2}{*}{ Satuan } & \multirow{2}{*}{ MDL } & Sampel & \multirow{2}{*}{ Rekomendasi } \\
\cline { 5 - 5 } & & & & L.3884 & \\
\hline
\end{tabular}

Sumber: Hasil Penelitian, 2014

5) Suhu

Suhu suatu air dipengaruhi oleh musim, lintang, ketinggian dari permukaan laut, waktu dalam hari, sirkulasi udara, penumpukan awan dan aliran kedalaman air. Dari hasil di laboratorium suhu pada air sungai 27,8 OC. berdasarkan keputusan mentri kesehatan no 429 /Menkes/per/IV/tahun 2010. Suhu udara maksimal 3. Jadi dari 
hasil penelitian yang didapat dari laboratorium tidak memenuhi syarat yang ditetapkan mentri kesehatan no
492/Menkes/per/IV/tahun 2010. Untuk lebih jelasnya dapat dilihat pada tabel 6 berikut ini.

Tabel 6. Hasil Penelitian suhu Air Sungai Batang Manggilang

\begin{tabular}{|l|c|c|l|c|c|}
\hline \multirow{2}{*}{ No } & \multirow{2}{*}{ Parameter } & \multirow{2}{*}{ Satuan } & \multirow{2}{*}{ MDL } & Sampel & \multirow{2}{*}{ Rekomendasi } \\
\cline { 5 - 5 } & & & & L. 3884 & \\
\hline 1 & Suhu & $0_{\mathrm{C}}$ & - & 27,8 & Tidak Memenuhi Syarat \\
\hline
\end{tabular}

Sumber: Hasil Penelitian, 2014

b. Sifat Kimia Air sungai

1) $\mathrm{pH}$

$\mathrm{pH}$ kualitas air sungai yang diperoleh dari keputusan mentri kesehatan no 429 /Menkes/per/IV/tahun 2010 yaitu $6,5-8,5 \mathrm{mg} / \mathrm{L}$. Hasil pengukuran yang dilakukan di laboratorium menunjukkan bahwa $\mathrm{pH} 0,1$. Pada daerah penelitian ini tidak memenihi syarat minimum. Untuk lebih jelasnya dapat dilihat pada Tabel 7 berikut ini.

Tabel 7. Hasil Penelitian pH Air Sungai Batang Manggilang

\begin{tabular}{|c|c|c|c|c|c|}
\hline \multirow{2}{*}{ No } & \multirow{2}{*}{ Parameter } & \multirow{2}{*}{ Satuan } & \multirow{2}{*}{ MDL } & Sampel & \multirow{2}{*}{ Rekomendasi } \\
\cline { 5 - 5 } & & & & L.3884 & Tidak memenuhi syarat \\
\hline
\end{tabular}

Sumber: Hasil Penelitian, 2014

2) Zat Tersuspensi

Berdasarkan keputusan mentri kesehatan no 429 /Menkes/per/IV/tahun 2010. Zat Tersuspensi (TSS) $500 \mathrm{mg} / \mathrm{L}$. Hasil yang didapatkan dari dilaboratorium menunjukkan bahwa Zat Tersuspensi
(TSS) 400. Jadi dari hasil penelitian yang didapat dari laboratorium tidak memenuhi syarat yang ditetapkan menteri kesehatan no 492/ Menkes/ per/ IV/tahun 2010. Untuk lebih jelasnya dapat dilihat pada Tabel 8 berikut ini.

Tabel 8. Hasil Penelitian Zat Tersuspensi Air Sungai Batang Manggilang

\begin{tabular}{|c|c|c|c|c|c|}
\hline No & Parameter & Satuan & MDL & Sampel & \multirow{2}{*}{ Rekomendasi } \\
\cline { 5 - 5 } 1 & $\begin{array}{c}\text { Zat } \\
\text { tersuspensi }\end{array}$ & $\mathrm{mg} / \mathrm{L}$ & 01,53 & 400 & Tidak memenuhi syarat \\
\hline
\end{tabular}

Sumber: Hasil Penelitian, 2014

3) Besi (Fe)

Kandungan besi pada air sungai yang diperoleh dari keputusan mentri kesehatan no 429 /Menkes/per/IV/tahun 2010 yaitu 0,2 mg/L. Hasil yang dilakukan di laboratorium menunjukan bahwa 0,003 . Jadi kandungan besi pada air sungai di daerah penelitian ini tidak memenuhi syarat minim. Untuk lebih jelas nya dapat dilihat pad Tabel 9 berikut ini.

Tabel 9. Hasil Penelitian Bau Air Sungai Batang Manggilang

\begin{tabular}{|c|c|c|c|c|c|}
\hline No & Parameter & Satuan & MDL & sampel & rekomendasi \\
\hline 1 & Besi & $\mathrm{Mg} / \mathrm{L}$ & 0,003 & $\begin{array}{c}\text { L.3884 } \\
307 \\
\end{array}$ & Tidak \\
\hline
\end{tabular}

Sumber: Hasil Penelitian, 2014

\section{KESIMPULAN}

Berdasarkan pembahasan hasil penelitian sifat fisika dan kimia pada air sungai Batang Manggilang Kenagarian Manggilang jorong Sebrang Pasar Manggilang 
Kabupaten 50 Kota. Makan hasil penelitian disimpulakan sebagai berikut:

1. Kondisi Fisika (Warna, rasa, bau, kekeruhan, suhu) didaerah kenagarian manggilang yang berada dekat sungai batang manggilang sesuai dengan uji labioratorium bahwa air sungai ini tidak memenuhi syarat untuk dipergunakan oleh masyarakat yang berada di sekitar pinggiran sungai Batang Manggilang. Karena sudah tercemari oleh keberadaan tambang batu bara.

2. Kondisi Kimia tidak memenuhi syarat yang ditetapkan Mentri Kesehatan No 492/menkes/Kondisi Fisika (Warna, rasa, bau, kekeruhan, suhu) di daerah kenagarian manggilang yang berada dekat sungai batang manggilang sesuai dengan uji laboratorium bahwa air sungai ini tidak memenuhi syarat untuk dipergunakan oleh masyarakat yang berada di sekitar hulu sungai batang manggilang. Karena sudah tercemari oleh keberadaan tambang batu bara. Kandungan Besi pada air sungai di daerah penelitian ini tidak memenihi syarat minimum. Karena tercemarnya sungai akibat dari pertambangan batu bara yang berada di hulu sungai batang manggilang.

\section{DAFTAR PUSTAKA}

Arikunto, S. (2009). Metode penelitian. Jakarta: Rineka Cipta, 8971.

Astuti, A. J. D., \& Berutu, N. (2012). Studi Mengenai Koefisien Aliran Sebagai Indikator Kerusakan Lingkungan Di Daerah Aliran Sungai Deli. JURNAL GEOGRAFI, 4(1), 1-14.

Dep. Kes RI. (2010). Standar Kualitas Air sungai. Jakarta: Dep.Kes RI.

Jamilatun, S. (2008). Sifat-sifat penyalaan dan pembakaran briket biomassa, briket batubara dan arang kayu. Jurnal Rekayasa Proses, 2(2), 37-40.

Maleong, L. (2007). Metodelogi Penelitian. Bandung. PT. Remaja Rosdakarya.

Manik, J. D. N. (2013). Pengelolaan Pertambangan Yang Berdampak Lingkungan Di Indonesia. PROMINE, 1(1).

Marganingrum, D., \& Noviardi, R. (2009). Pencemaran Air dan Tanah di Kawasan Pertambangan Batubara di PT. Berau Coal, Kalimantan Timur. Riset Geologi dan Pertambangan, 20(1), 11-20.

Peraturan mentri kesehatan, No 8 Tahun 2001. Jakarta: Dep.Kes RI.

Lallanilla, M. (2016). Enam Masalah Lingkungan Teratas di Cina.Bandung. medika citra.

Sulaksono, A. (2015). Pengaruh investasi dan tenaga kerja terhadap pdb sektor pertambangan di Indonesia. Jurnal Ilmiah Ekonomi Bisnis, 20(1).

Sutedi, A. (2016). Legal Aspects of Procurement of Goods and Services, and Various Problems, Jakarta. Sinar Grafika.

UU 1945 Pasal 33 ayat 3. Peraturan pertambangan. Jakarta: Sinar Grapika.

Widyati, E. (2009). Kajian fitoremediasi sebagai salah satu upaya menurunkan akumulasi logam akibat air asam tambang pada lahan bekas tambang batu bara. Tekno Hutan Tanaman, 2(2), 67-75.

Wiryono. (2017). Pengantar Ilmu Lingkungan. Jurnal Pertelon Media. Bengkulu. 